\title{
The building stone of the Roman city of Lixus (NW Morocco): provenance, petrography and petrophysical characterization
}

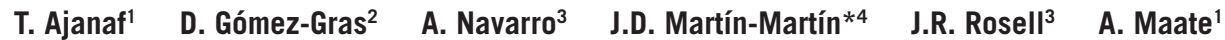 \\ 'Département de Géologie, Faculté des Sciences-Tétouan, Université Abdelmalek \\ Essaadi Maroc \\ Avenue de Sebta, 93003 Tétouan, Maroc. Ajanaf E-mail: ajanaf01@gmail.com \\ ${ }^{2}$ Departament de Geologia, Universitat Autònoma de Barcelona \\ 08193 Bellaterra (Cerdanyola del Vallès), Spain. Gómez-Gras E-mail: david.gomez@uab.cat \\ ${ }^{3}$ Departament de Tecnologia de l'Arquitectura, Escola Politècnica Superior \\ d'Edificació de Barcelona, UPC \\ 08028 Barcelona, Spain. Navarro E-mail: antonia.navarro@upc.edu \\ ${ }^{4}$ Departament de Mineralogia, Petrologia i Geologia Aplicada, Facultat de Ciències de la Terra, \\ Universitat de Barcelona (UB) \\ 08028 Barcelona, Spain. Martín-Martín E-mail: juandiegomartin@ub.edu
}

${ }^{*}$ Corresponding author

\section{A B S T R A C T}

The characterization of building materials is a key tool to assess deterioration processes and improve potential restoration works of archaeological sites. The aim of this paper is to identify and characterize the most important building stones used in the construction of the Roman city of Lixus (Larache, Morocco) by means of petrographic and petrophysical techniques. Based on the visual analysis of the monuments, three major building stones (i.e. lithotypes) have been identified: i) Oligocene sandstones, ii) Quaternary sandstones and iii) Quaternary conglomerates. Based on the analysis of the regional geology and exploitation marks, these three lithotypes have been recognised to crop out in the surroundings of Lixus and the quarries, presumably Roman in origin, recognized. The Oligocene sandstone is the primary building stone in Lixus as it forms and crops out extensively in the Tchemmis hill, at the top of which the city is settled. The Quaternary sandstones and conglomerates, which represent nearshore deposits and eolianites, crop out along the Atlantic coast where they form part of the cliffs next to Larache.

Petrographic results indicate that lithotypes differ notably in grain size, ratio of detrital to allochemical components, and the configuration of their porous system. Mechanical analysis shows that the Oligocene sandstones are more resistant to compression than the Quaternary sandstones and conglomerates, the latter exhibiting relatively low compressive strength. The Oligocene sandstones, which display scarce porosity and permeability, show a hydric behaviour characterized by a very low degree of absorption and desorption water, likely resulting from a poor connectivity of the pore network. Contrary to the latter lithotype, the Quaternary sandstones, which exhibit very high porosity and permeability, display a hydric behaviour characterized by high degree of both absorption and desorption of water. This is attributed to the low degree of cementation compared to porosity of this lithotype and the excellent connectivity of the porous network. Finally, Oligocene and Quaternary sandstones do not show a significant weight loss after the accelerated artificial aging test, indicating that both are slightly affected by salt crystallization and presumably ice formation. Results indicate that the relatively fine state of conservation of the building rocks of Lixus is linked to intrinsic factors such as mineralogy and petrophysical characteristics together with the favourable effect of the climatic condition of the study area.

KEYWORDS Building stone. Lixus. Petrography. Petrophysics. Durability.

(C) T. Ajanaf, D. Goméz-Gras, A. Navarro, J.D. Martín-Martín, J.R. Rosell, A. Maate, 2020 CC BY-SA 


\section{INTRODUCTION}

Alteration and preservation of architectural heritage is challenging both culturally and scientifically (Beck et al., 2003). The restoration of ancient monuments is usually done by replacing the most damaged rock material. Whenever possible, the building stones used in restoration should be of the same rock type or have similar petrophysics characteristics than the replaced ones. Unfortunately, the number of quarries that can provide restoration sites are limited compared to the variety of stones originally used. In this regard, the juxtaposition of stones of similar appearance but of different petrophysical nature on a monument can accelerate the degradation of one of them or both (Beck et al., 2003; Beck and Al-Mukhtar, 2005; Derbez and Lefèvre, 2003). Therefore, a major issue that arises during restoration processes is the compatibility between the original building stones and the rock types used as a replacement.

The identification and characterization of building stones used in the construction of archaeological sites is a key tool to evaluate deterioration processes and improve future restoration works (Zoghlami et al., 2017). Deterioration of building stones by weathering is a natural process that occurs in all type of rocks exposed to atmospheric environment (Siedel and Siegesmund, 2014). In this regard, the description and interpretation of the diverse types of rock weathering, and the driving forces behind them, have been a subject of interest in geosciences such as geomorphology and physical geography for many years (Robinson and Williams, 1994; Turkington and Paradise, 2005). The degree of weathering is strongly related to petrophysics properties of the rock as well as environmental conditions. Common alteration features on rock materials are typically characterized by an increase in porosity of the altered rock, a process that has been accentuated in the last century by the rapid development of atmospheric pollution and by the aggressiveness of the environment (Beck et al., 2003; Price, 1995). In this regard, water commonly is the main driving force of weathering and it can affect the rock directly (by the effect of ice and mineral dissolution, among others) and indirectly (transport of soluble salts and favouring biological activity, among others) (Andriani and Walsh, 2007; Ruedrich et al., 2007). Most rock alteration processes involve water and salts and use to develop in close association with the flow of fluids through the pore system. Among weathering agents, the soluble salts play a major role in the degradation of the stones used in construction. Halite $(\mathrm{NaCl})$ and gypsum $\left(\mathrm{CaSO}_{4} 2 \mathrm{H}_{2} \mathrm{O}\right)$ are the most common and most destructive salts. Thus, many alteration studies have been carried out in the laboratory to observe the behaviour of building stones to diverse weathering agents (Benavente, 2011; Goudie, 1999). Rock alteration studies have focused over the last decades on sedimentary rocks, and most particularly on limestones and arenites (Dessandier et al., 1997; Martínez-Martínez et al., 2017a, b; Zoghlami et al., 2017).

The Quaternary nearshore deposits that crop out along the coastal areas of the Mediterranean countries are typically used in the construction of most important historic monuments (e.g. El Djem and the cities of Utica and Cartago in Tunisia) due to the facility to quarry and shape such rocks. Within these Tyrrhenian deposits many historic quarries were opened to supply building stones to a large number of monuments of cities in Tunisia (e.g. Bizerte, Tunis and Monastir), in Sicily (e.g. Palermo, Marsala) and in Balearic Islands. However, the study of this type of rock is not abundant in the literature and their characterization needs proper attention. These Quaternary sediments are common building rocks in the construction of classic monuments both in the NW of Morocco as Benasa and Thamusida (Ouacha et al., 2013), and in Rabat as Roman challah (Zaouia et al., 2014). In this regard, the Quaternary (Tyrrhenian) sandstones and conglomerates of the Atlantic coast of Larache, together with the Tchemmis Oligocene sandstones, are the most common building stones used in the ancient City of Lixus (Morocco). Therefore, the study of Lixus gives a great opportunity to increase our knowledge of this type of rock.

Potential restoration works of Lixus will need abundant and diverse information regarding the origin and characteristics of the building rocks for a correct replacement process. Such characterization includes the determination of the petrographic, hydric and mechanical properties, together with the accelerated artificial aging test (Borrelli and Urland, 1999; De Kock et al., 2015; Esbert and Marcos, 1983; Esbert et al., 2008; Gauri and Punuru, 1989; Lazzarini and Laurenzi Tabasso, 1986; López-Arce et al., 2009; Ordoñez et al., 1997; Villegas and Vale, 1993; Winkler, 1975).

The goal of this paper is to identify and characterize most important building stones used in the construction in the city of Lixus (NW Morocco). Specifically, the objectives are: i) to identify the main lithotypes used, ii) to recognize the rock formations and specific sites from where the lithotypes were quarried, iii) to characterize the petrology of the lithotypes and iv) to characterize the petrophysics properties of the lithotypes.

\section{GEOGRAPHIC LOCATION AND CLIMATE}

Lixus is an archaeological site located about $3 \mathrm{~km} \mathrm{NE}$ of Larache (NW Morocco), on the right bank of the Loukkos River (Figs. 1; 2; 3A-B). Lixus is considered one of the oldest cities of the West Roman Empire together with Cadiz 


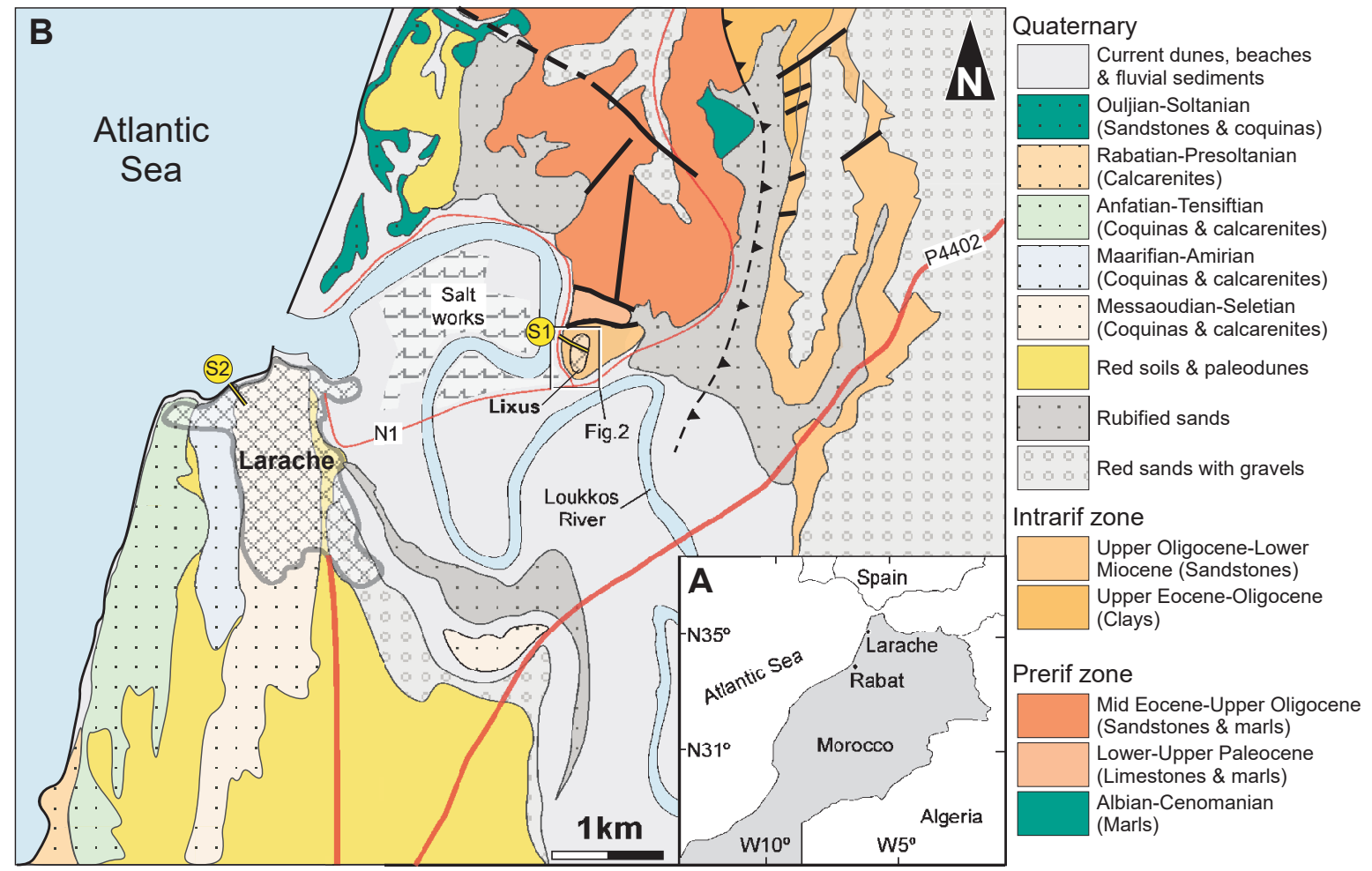

FIGURE 1. A) Map of Morocco showing the location of Larache. B) Geological map of the Larache area showing the location of the Roman City of Lixus (Modified from Haddane, 1997). The location of the studied stratigraphic sections are noted as S1 (Tchemmis section) and S2 (Larache Cliff section).

(Spain) and Utica (Tunisia) (Ponsich, 1966). The ruins of the city represent the pass of diverse civilizations, starting as Phoenician and followed by Punic, Mauritanian, Roman, and finally Islamic (Ouacha et al., 2013). The city is endowed with several public monuments such as an amphitheatre, temple area and private baths richly decorated with frescoes and mosaics of good quality (Fig. 3). In addition, the city has a large industrial complex for the elaboration of salted brine and salted fish (Fig. 3F), being the salt produced in a work complex located in the vicinity of the city (Figs. 2; 3A-B). Most Lixus buildings are partially to completely ruined and numerous original rock elements are broken or disappeared (Figs. 3BF; 4A). Moreover, the remaining building rocks frequently present alteration patterns such as fissures, surface erosion, fragmentation and biological colonization (Fig. 3B-F).

Regarding the climate of the studied area, the region of Larache is located in the Atlantic coast of northwest of Morocco (Fig. 1). Lixus has a warm-temperature Mediterranean climate, with a hot and dry summer, classified as Csa according to the Köppen-Geiger climate system (Kottek et al., 2006). The average annual temperature is $17.9^{\circ} \mathrm{C}$, with a minimum average value of $13.5^{\circ} \mathrm{C}$ and a maximum average value of $25.5^{\circ} \mathrm{C}$ and a strong seasonality, with monthly temperature variations ranging between $9^{\circ} \mathrm{C}$ in January and $30^{\circ} \mathrm{C}$ in August. The annual average rainfall of the area is approximately $650 \mathrm{~mm}$. The climate is subhumid and characterized by two very different seasons. From October to April, the climate is humid and cool, and concentrates up to $90 \%$ of the annual rainfall. From May to September the climate is dry and hot, being the rainfall virtually zero in the month of July (Bouhmadi et al., 1995). The wind regime on the western coast of Morocco is closely related to the Azores anticyclone and the North Atlantic depressions (El Gharbaoui, 1981; El Moutchou et al., 2014). Therefore, the prevailing winds in the Larache area come from the west (Atlantic Ocean) with average wind speed above $15 \mathrm{~km} / \mathrm{h}$. During the summer, these winds alternate near the coast with the East Chergui wind of continental origin (El Mekadem and Moutchou, 2016). The relative humidity is relatively high due to the proximity to the Atlantic Ocean, ranging between 66-70\% in winter and $55 \%$ in summer. The River Loukkos, which is about $180 \mathrm{~km}$ long and has a basin area of $3750 \mathrm{~km}^{2}$, flows into Larache developing an extensive fluvial plain with channels and meanders at the foot of the Tchemmis hill.

\section{GEOLOGICAL SETTING}

The region of Larache belongs to the Habt Atlantique Intrarif unit, which is exposed in the western part of the 


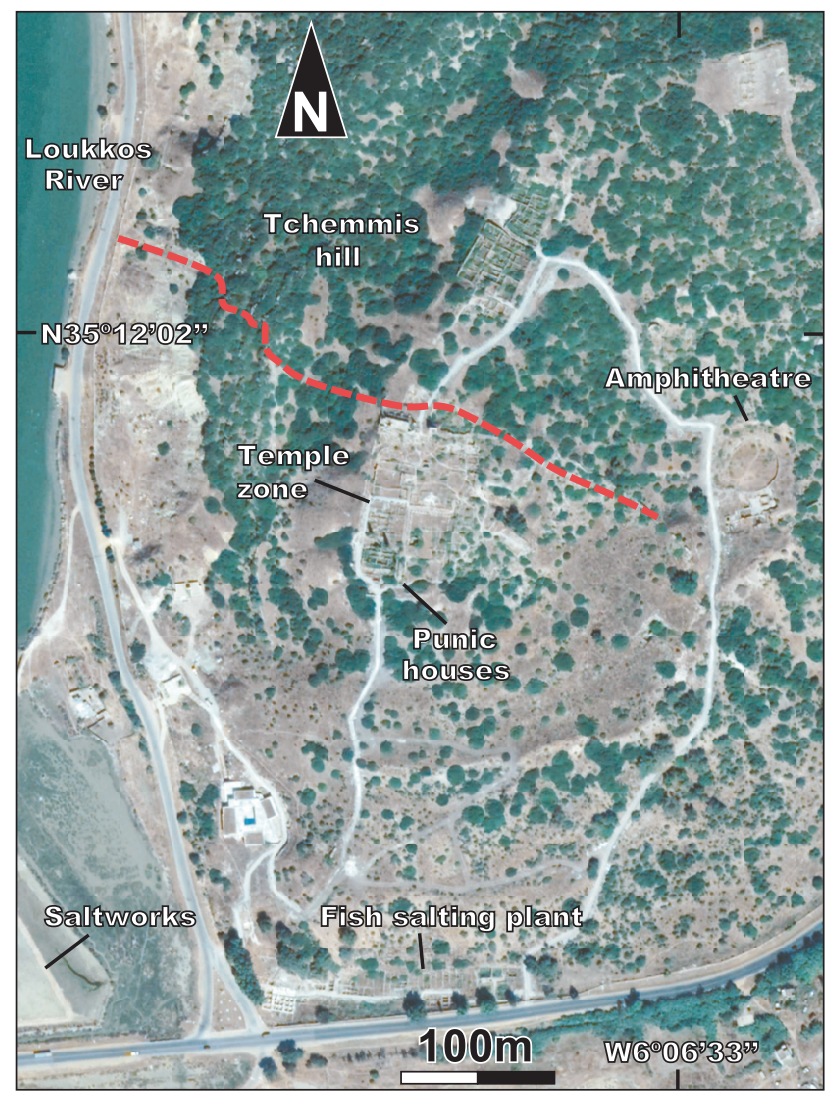

FIGURE 2. Google Earth image of the Tchemmis hill showing the aeria view of Lixus (See location in Figure 1). The red dashed line denotes the trace of the Tchemmis section.

Rif Chain in the northwest of Morocco (Lespinasse, 1975; Samaka et al., 1997) (Fig. 1). This area constitutes the western termination of the Maghrebian Alpine Chain that extends along the Mediterranean coast of North Africa from Calabria to the Arch of Gibraltar (Chalouan et al., 1990, 2001; Didon et al., 1973; Durand Delga, 1964). Specifically, the study area is located in the external domain of the Rif Chain and it is affected by the Habt nappe.

The Habt Unit has been the subject of several studies since middle last century (Abdelkhaliki, 1997; Cazzola and Critelli, 1987; Morley, 1987; Samaka et al., 1997; Suter, 1986; Suter and Fiecher, 1966; Tejera de León et al., 1995). Structurally, it belongs to the external domain of the Rif Chain, and is bounded in the west by the internal Prerif and in the east by the Tangier Unit series. The Habt Unit is Eocene to Middle Miocene in age and is made of gravity deposits representing the filling of deep submarine cones at the trough of the syn-orogenic depression (Abdelkhaliki, 1997). The general stratigraphic succession is organized in three superimposed formations (Tejera de León et al., 1995): i) the Upper Eocene-Oligocene clays of the Sahel Fm. ii) the Upper Oligocene-Lower Miocene sandstones and clays of the Asilah Fm. and iii) the Middle Miocene marls of the Sidi Moussa Fm., The Asilah Fm. form and crops out in the Tchemmis hill, where the Roman City of Lixus is located, being the most used building stone in its construction.

The Quaternary deposits that crop out along the Atlantic coast of Morocco, which are irregularly distributed, have been widely reported in the literature (Aboumaria et al., 2009; Akil and Gayet, 1988; Beaudet, 1971; Chabli et al., 2014; Chouber and Roche, 1956; Gigout, 1947; Ouadia, 2015). These deposits are mainly made of conglomerate, sandstones and bioclastic limestones (i.e. coquinas) that are the result of successive Quaternary marine transgressions (Akil and Gayet, 1988). The conglomerates are frequently made of abundant broken to fully preserved shells of marine molluscs mixed with clastic sediments. They commonly show flat or slightly oblique lamination to the sea indicating medium to strong energy of deposition. The Quaternary sandstone deposits are the result of the wave and wind action witnessed by the abundance of round quartz grains and rock fragments. In the coast of Larache the Quaternary sediments show an evolution from intertidal foreshore marine to backshore or dune aeolian deposits.

\section{MATERIALS AND METHODS}

The characterization of the building stone used in the construction of the Roman City of Lixus was accomplished in two steps. Firstly, the buildings were recognized by visual analysis and major rock types (i.e. lithotypes) were identified based on lithology and abundance (Figs. 3; 4). Small pieces of the selected lithotypes up to $5 \mathrm{~cm}$ long have been sampled from the monuments, mostly from loose and broken blocks, in order to perform thin sections for the petrographic study described below. Secondly, the geology of the region surrounding Lixus was analysed in order to identify potential exposures of the rocks that were the origin of such lithotypes. In addition, two stratigraphic sections of such exposures were logged in order to identify and locate the strata that provided these lithotypes (i.e. Roman quarries). The first stratigraphic section was measured at the Tchemmis hill where the Oligocene sandstone crop out under the city of Lixus (Figs. 1; 2; 3; 4). The second stratigraphic section was measured at the Larache cliff, near the Sidi Abdelah cemetery, where the Quaternary sandstones, conglomerates and coquinas crop out extensively (Figs. 1; 3; 4). The selected lithotypes have been sampled directly from the quarries in order to perform the petrophysical and the accelerated artificial aging analyses described below.

The petrographic study was carried out by analysing standard thin sections in an optical microscope in accordance with the standard test UNE-EN 12407 

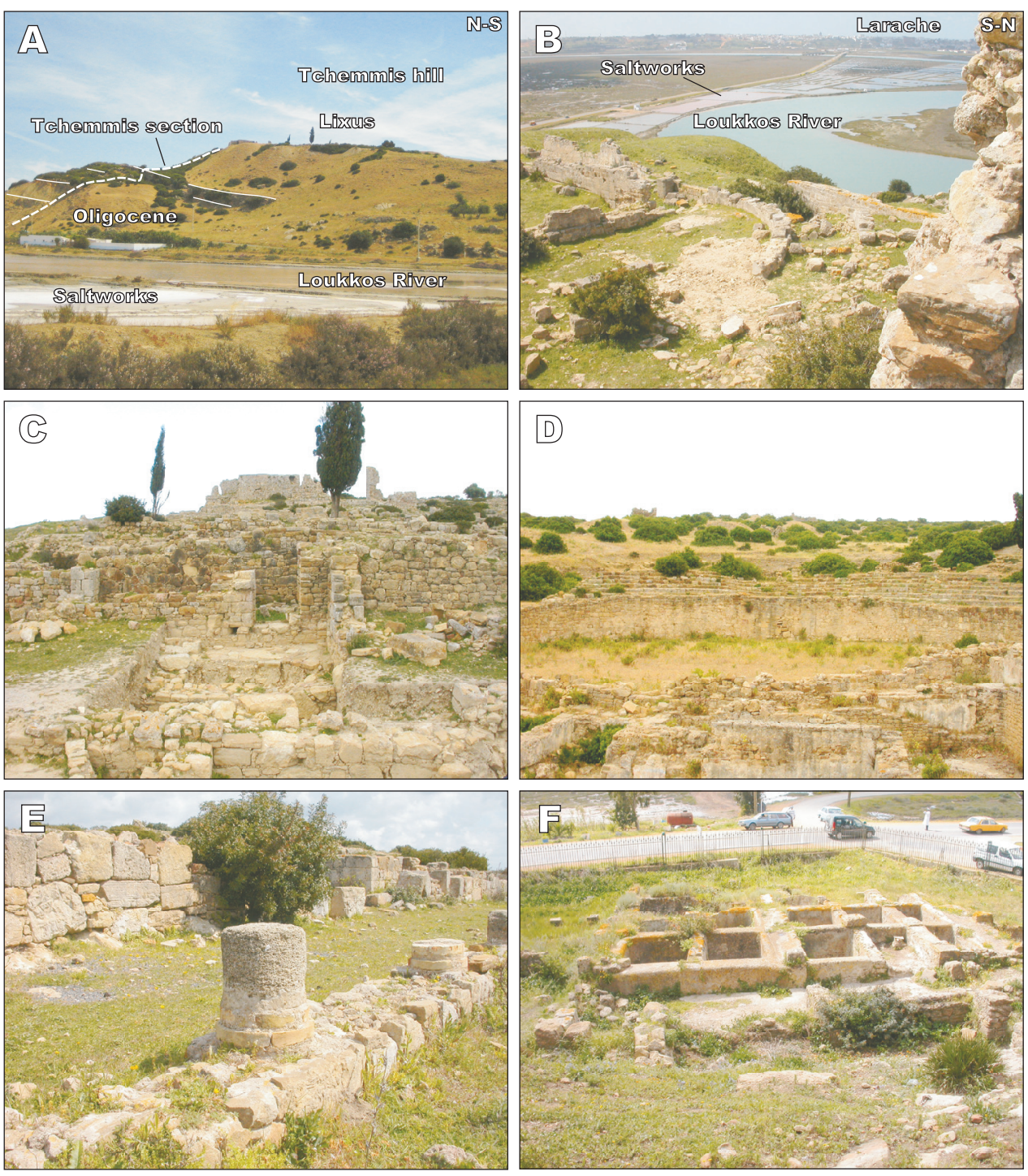

FIGURE 3. Field views of Lixus showing: A) The Tchemmis hill and the trace of the Tchemmis section following the structural steps related to the exposure of the Oligocene sandstones. B) The Tchemmis Hill west view with the Loukkos River and the city of Larache in the background. C) The Temple district. D) The Amphitheater. E) The Quarter of the temples with partially ruined columns made of Quaternary sandstones. F) The complex for the production of salted fish.

(2007). Microscopic observations allow recognizing rock components (qualitative and quantitative mineralogy, and textural relationship between components) and the pore system (qualitative and quantitative porosity, and relationship between voids and components). Comparison between thin sections from both monument and quarry was done in order to confirm that the petrographic characteristics, and thus lithotypes, are the same.

The petrophysical properties, which include total open porosity, water absorption and desorption, compressive strength, and accelerated artificial aging, were determined by standard tests. These tests are typically used to determine the durability of building materials and to test their resistivity against various deterioration factors (Zoghlami et al., 2004). Measurements were carried out in $5 \times 5 \times 5 \mathrm{~cm}$ cubes (six cubs for each lithotype). Due to the difficulty of shaping such cubes from the Quaternary conglomerates, which is related to the high degree of porosity and the presence of large lithic and skeletal fragments, water and durability tests have been only performed in the Oligocene and Quaternary sandstones.

The total open porosity of the Oligocene and Quaternary sandstones was measured by the vacuum absorption test (UNE-EN 1936, 2007). By contrast, the vacuum absorption test was not performed in the Quaternary conglomerate due to the large pore diameter ( 5 to $12 \mathrm{~mm}$ ). According to the method described by Beck and Al-Mukhtar (2005), the total open porosity of the Quaternary conglomerate was 

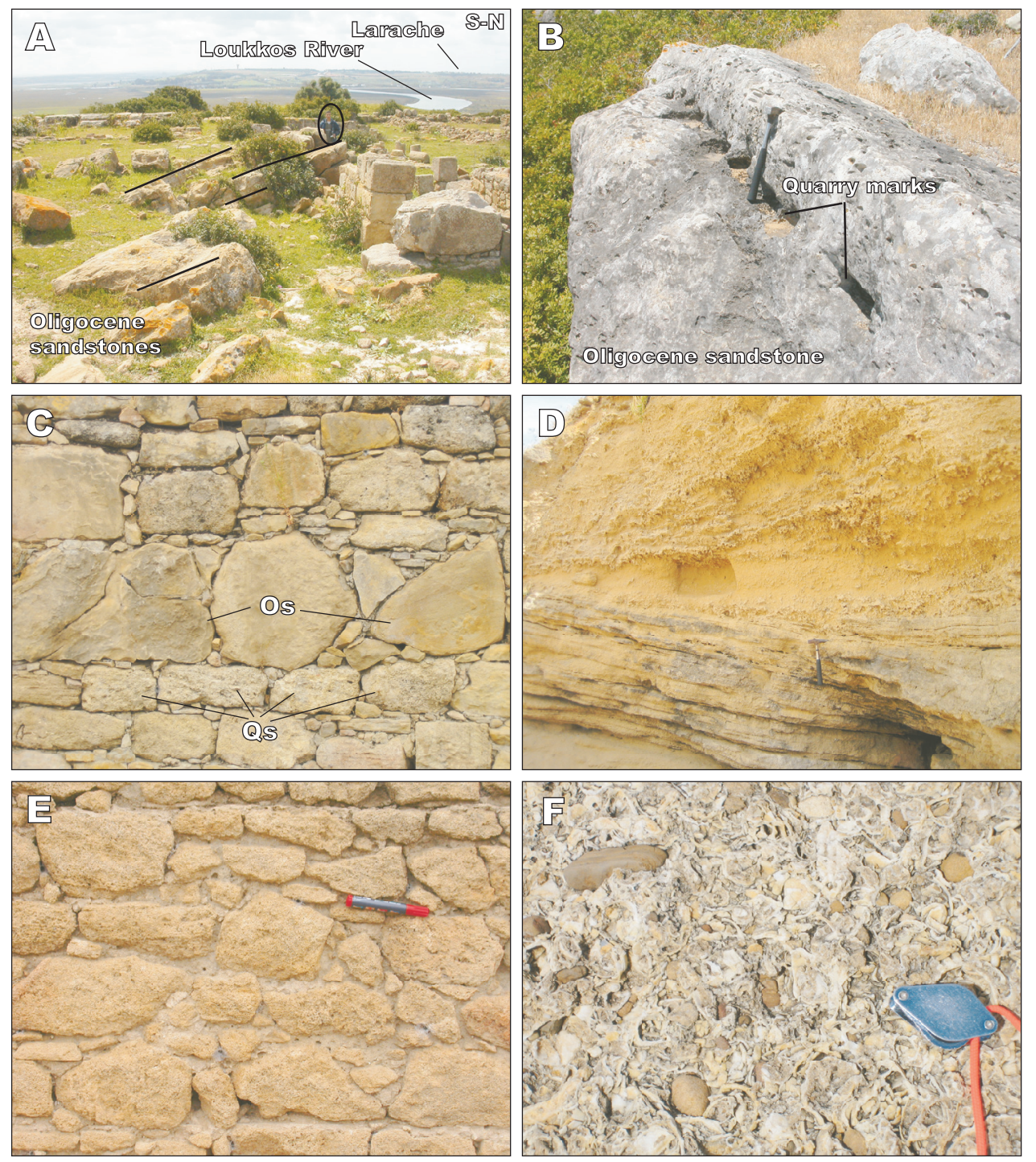

FIGURE 4. Field views of the building rocks used in the construction of Lixus. A) Top of the Tchemmis Hill showing Oligocene sandstone strata cropping out within the city. Note how the strata is used as part of the walls. B) Oligocene sandstone exposures in the side of the Tchemmis hill showing marks of extraction, presumably roman in origin. C) Wall of the amphitheatre showing blocks of the Oligocene sandstone (Os) and Quaternary sandstone (Qs) lithotypes. (D) Detail of the Larache cliff section showing Quaternary sandstones both well cemented (bottom) and poorly cemented (top). E). Detail of the wall of the amphitheatre showing abundant blocks of Quaternary sandstone. F) Shell-rich conglomerate in the Larache cliff.

determined taken into account the apparent density $(\rho a)$, which represents the mass of minerals relative to the total volume of the stone, and the density of the solid skeleton ( $\rho s$, which represents the mass of minerals relative to the total volume of grains.

The hydric tests that have been performed include water desorption and water absorption. The water desorption test allows determining the percentage of water retention (Se) carried out under $40 \%$ moisture conditions and at a temperature of $20^{\circ} \mathrm{C}$, according to the standard test of NORMAL 29/88 (1988). The water absorption test allows determining the Capillary Absorption Coefficient c.A.C $\left(\mathrm{kg} /\left(\mathrm{m}^{2 *} \mathrm{~h} 1 / 2\right)\right)$, which indicates the rate of water suction by capillarity in accordance with the standard test UNEEN 1925 (1999). Both hydric tests have been performed on six cubes for each lithotype although the reported data correspond to most significant values.

The mechanical properties are based on the compressive strength test according to the standard UNE-EN 1926 (2007). The test has been performed in 6 cubes for each lithotype, being the presented value the average one. The accelerated artificial aging was performed in order to determine the durability or degree of alteration of the rock by salt crystallization. It consists of 12 cycles of immersion 
in a solution saturated in sodium sulphate followed by drying in oven at $100^{\circ} \mathrm{C}$ in accordance with the standard test UNE-EN 12370 (1999). The test favours the crystallization of the salt in the pore system and allows determining the associated increase or decrease of mass. The sodium sulphate was the salt chosen to this experiment because it is considered the most aggressive alteration agent on rocks as suggested by Zehnder and Arnold (1989).

\section{RESULTS}

\section{Identification of major building stones}

Visual analysis of the building stone of Lixus allows recognizing three major lithotypes used in the construction of the city: i) Oligocene sandstone, ii) Quaternary sandstone and iii) Quaternary conglomerate. The Oligocene sandstone is by far the most common lithotype and is specially used as large blocks for the construction of the walls of temples and houses (Figs. 3C-D; 4A-C). The Quaternary sandstone, especially fine to medium-grained bioclastic sandstones, is mainly used in the construction of columns as well as in the construction of the walls of houses and temples (Fig. $4 \mathrm{E})$. The Quaternary conglomerate, especially microconglomeratic facies, is dominantly used in the construction of the base of the columns (Fig. 3E).

\section{Petrological characterization of quarry rocks}

Field logging and sampling of the Lixus and Larache cliff sections allows identify the cropping areas and most important macroscopic characteristics of the Oligocene and Quaternary lithotypes used in the construction of the Roman city of Lixus.

The Oligocene sandstones crop out extensively along the sides and on top of the Tchemmis hill (Fig. 2), being the strata frequently incorporated as part of the walls in the city buildings (Fig. 4A). The Lixus section is $216 \mathrm{~m}$ thick and represents the above-mentioned exposures starting in the base of the hill next to the Loukkos River and ending close to the amphitheatre (Figs. 2; 3A; 5). It is made of green to grey colour marls and marly limestones interbedded with carbonate sandstones (Fig. 4B). The sandstones form bed sets with individual beds around 1 to $5 \mathrm{~m}$ thick, showing erosive bases and channelshaped geometry. The sandstones are medium to fine grained in the base and very fine grained, and even silt sized, towards the top. They show cross-lamination that appear slightly disturbed probably associated with the escape of water during compaction. The sandstones are generally well cemented, which makes them optimal as construction rock. The exploitation of the sandstones directly from these exposures is noted by the presence of block extraction marks, presumably Roman in origin, in some of the sandstone beds in the hill sides (Fig. 4B).

The Quaternary sandstones and conglomerates used in the construction of Lixus were recognized to crop out in the coastal cliffs surrounding Larache. The Larache cliff section is $30 \mathrm{~m}$ thick and show two main units (Fig. $6)$. The lower unit is about $15 \mathrm{~m}$ thick and constitutes an alternation of decimetre thick beds of sandstones and conglomerates bounded by erosive bases. Sandstone beds are bioclastic-rich, medium to very coarse grained and frequently show scoured surfaces and medium-scale crossstratification. The conglomerate and microconglomerate beds are constituted by extrabasinal clasts mainly made of brown colour Eocene sandstones and quartz, together with minor intraformational pebbles of Quaternary sandstones. A shell-rich layer (i.e. coquina) occurs towards the top of the lower unit and consists of a $1.5 \mathrm{~m}$ thick bed of coarsegrained limestone mainly composed of shells and shell fragments of bivalves and gastropods (Fig. 4F). The lower unit is interpreted to have been deposited in a very energetic nearshore beach environment (shoreface-foreshore settings) near the shoreline.

The upper unit of the Larache cliff section, which overlay the shell-rich conglomeratic layer, is $15 \mathrm{~m}$ thick. It is made of highly porous and medium-grained sandstones (Figs. 4D; 6). Individual beds range between 5 and $8 \mathrm{~m}$ thick and show low angle cross-lamination and plane lamination parallel to the beach face and limited by scoured surfaces. To the top of the section shows large scale and high angle crossbedding representing the major foreset of aeolian dunes only disturbed by bioturbation marks made by root plants (rhizoliths). This upper unit is interpreted to represent a coastal dune setting (foreshore-backshore transition upwards) associated with sandy beaches represented by the lower unit.

The beds or bed sets that have similar petrographic characteristics to the three lithotypes identified in Lixus have been located in the logged sections (Figs. 5; 6). These beds have been sampled for petrophysical characterization both in terms of mechanical and hydric behaviour.

\section{Petrography of lithotypes}

The Oligocene sandstone is made up of very well sorted and rounded to sub-rounded grains, with an average diameter of $350 \mu \mathrm{m}$ (Fig. 7A; Table 1). The intrabasinal carbonate grains $(44.8 \%)$, which area dominated by red algae, foraminifera and bryozoan, are more abundant than the extrabasinal grains $(32.1 \%)$, which are largely dominated by monocrystalline quartz. The sandstone is well cemented by calcite $(21.2 \%)$. The porosity observable with this technique is very low $(1.9 \%)$, being the pores 


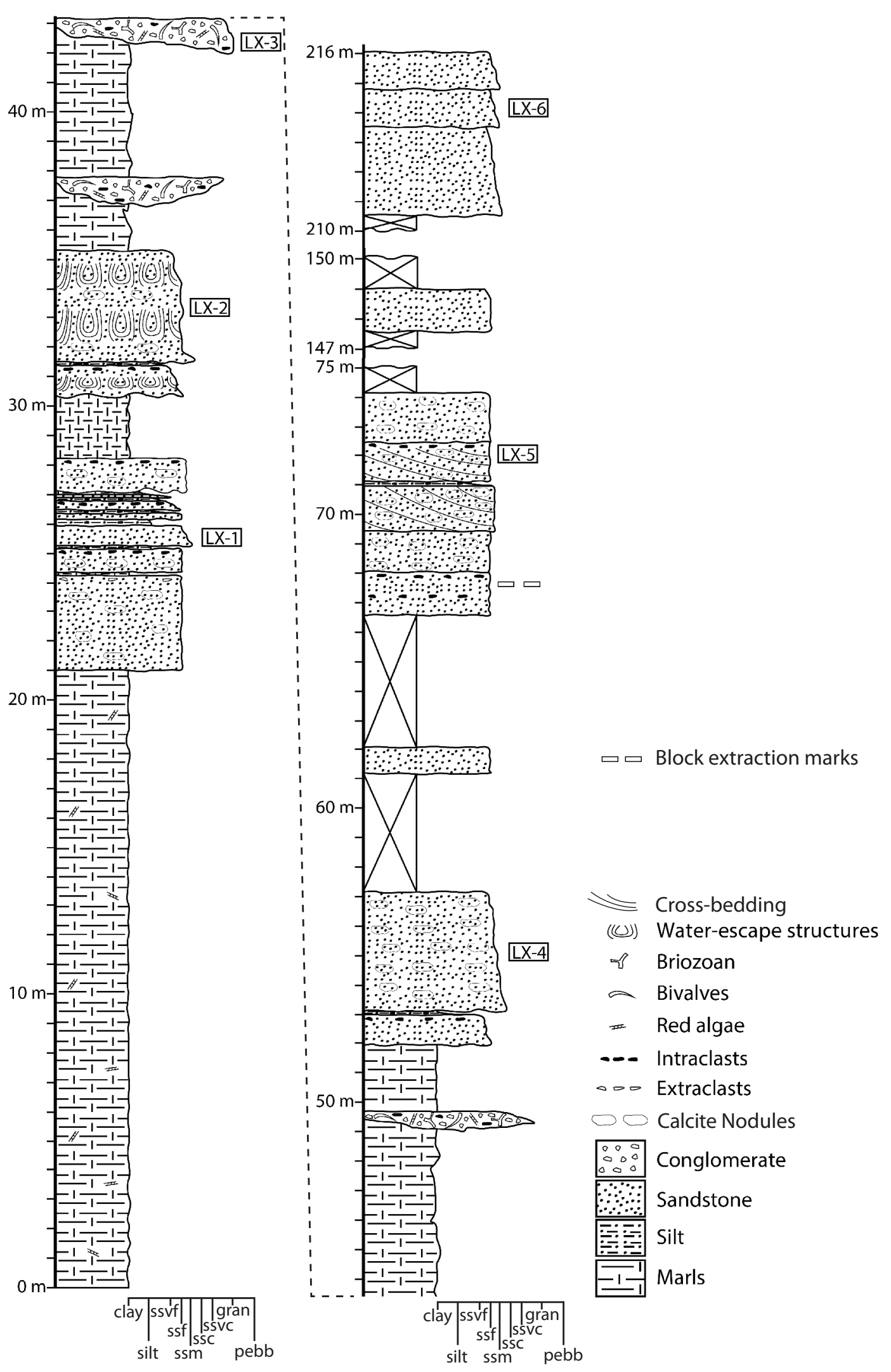

FIGURE 5. Stratigraphic section of the Tchemmis Hill showing the most important lithological characteristics of the Oligocene sediments and the location of the mined strata noted by block extraction marks. 


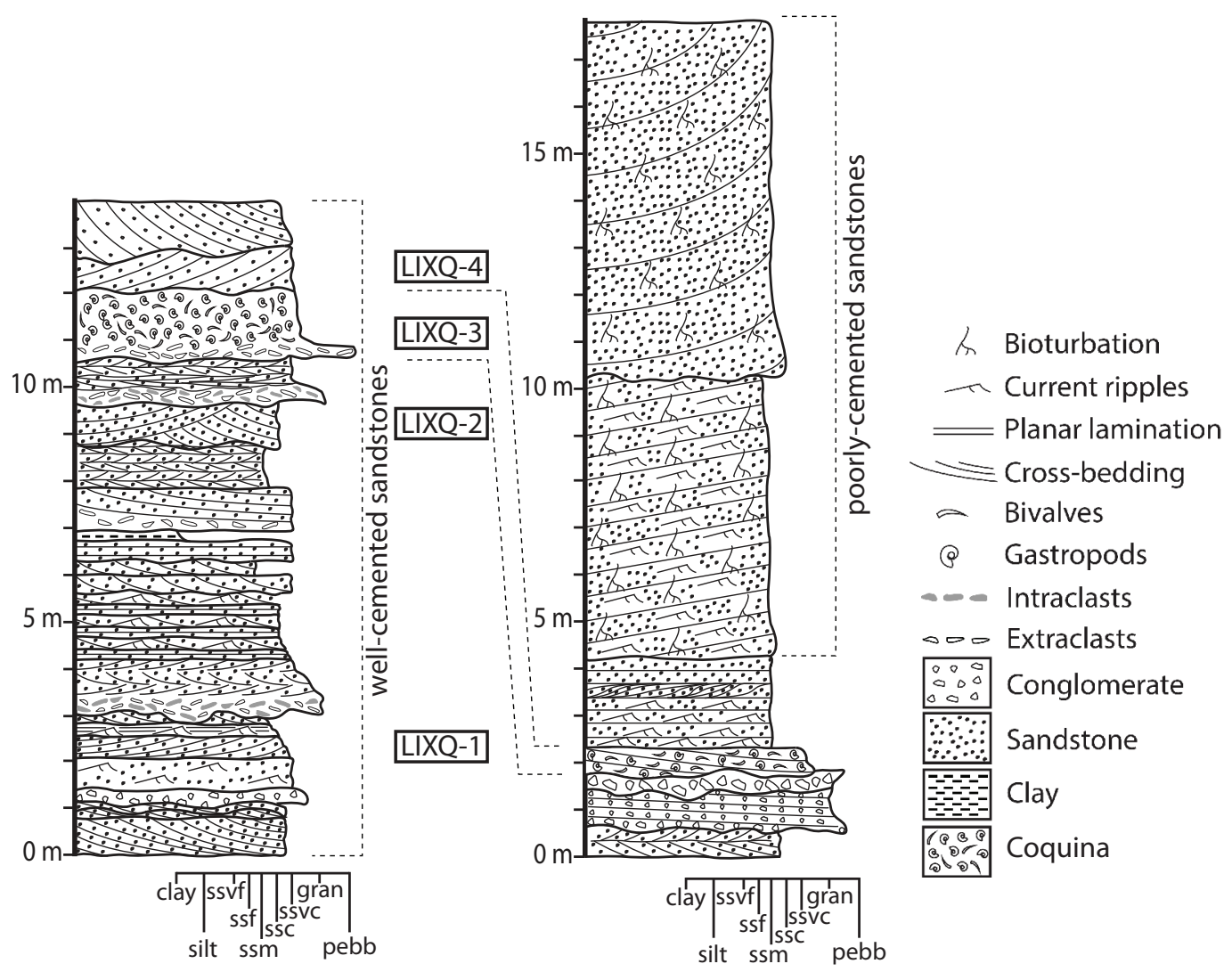

FIGURE 6. Stratigraphic section of the Larache cliff showing the most important lithological characteristics of the Quaternary sediments.

generally isolated and ranging between 50 and $250 \mu \mathrm{m}$ in diameter.

The Quaternary sandstone is made up of well sorted, and very well-rounded grains, with an average diameter between 0.3 and $1 \mathrm{~mm}$ (Fig. 7B; Table 1). The extrabasinal grains $(16.9 \%)$, which are dominated by monocrystalline quartz, are more abundant than the intrabasinal carbonate grains $(13.2 \%)$, which area dominated by bioclasts $(8.8 \%)$. Both the calcite cement $(26.2 \%)$ and the porosity $(26.8 \%)$ are very abundant. The pores show diameters ranging between 1 and $5 \mathrm{~mm}$.

The Quaternary conglomerate is a shell-bearing rock characterized by a very porous and relatively poorly cemented texture (Fig. 7C; Table 1). It is composed of coarse sized (5 to $12 \mathrm{~mm}$ ), poorly sorted, and wellrounded grains. The extrabasinal grains $(18.6 \%)$, which are dominated by monocrystalline quartz, are more abundant than the intrabasinal carbonate grains (15.2\%), which area dominated by bivalves and gastropods. The calcite cement is relatively poor $(15.2 \%)$ relative to porosity, which is very high and reaches up to $45.2 \%$, being the pores considerably bigger ( 5 and $12 \mathrm{~mm}$ ) than in other lithotypes.

\section{Water porosity}

The Oligocene sandstone shows a very low value of porosity accessible to water $(0.9 \%)$ compared to the Quaternary sandstones (30.9\%) (Table 2). These results are in agreement with the difference in apparent density of both lithotypes, being $2.65 \mathrm{~g} / \mathrm{cm}^{3}$ for the Oligocene sandstone and $1.87 \mathrm{~g} / \mathrm{cm}^{3}$ for the Quaternary sandstone. However, the relative density of the two lithotypes is very similar, being $2.68 \mathrm{~g} / \mathrm{cm}^{3}$ for the Oligocene sandstone and $2.71 \mathrm{~g} / \mathrm{cm}^{3}$ for Quaternary sandstone.

The total porosity of the Quaternary conglomerate based on real and apparent densities is relatively high (35.67\%), although it corresponds to a minimum value as most of the water was loss before carrying out the measurement. Therefore, the real value of porosity should be much higher, which agrees with the value reported from the petrographical description under the microscope (45.2\%; Table 1).

\section{Hydric and mechanical properties}

The water and durability tests have been performed only in the Oligocene sandstone and Quaternary sandstone 

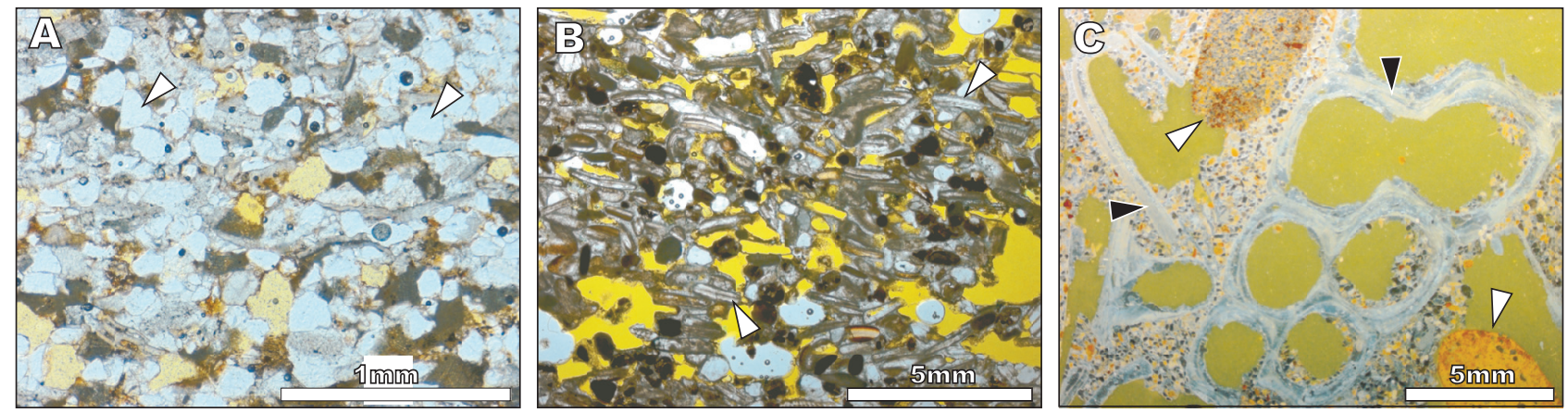

FIGURE 7. Photomicrographs of the studied lithotypes. A) Oligocene sandstone showing abundant quartz grains (arrows). B) Quaternary sandstone showing abundant fragments of bivalves (arrows). C) Quaternary conglomerate showing fragments of bivalves and gastropods (black arrows) and sedimentary rock fragments (white arrows). Note the abundant inter- and intragranular porosity (green colour).

lithotypes. By contrast, the large pore size of the Quaternary conglomerate makes the capillary tension very low and the hydric tests cannot be performed (Fort et al., 2002; Grossi and Esbert, 1994; Ordoñez et al., 1997). The Oligocene sandstone shows a maximum content of absorbed water that is considered very low $(0.35 \%)$ (Table 3$)$. The capillary absorption coefficient is also very small $\left(0.04 \mathrm{~kg} / \mathrm{m}^{2} . \mathrm{h} 1 / 2\right)$ as indicated in the capillary water suction curves (Fig. $8 \mathrm{~A})$. The rate of water absorption by capillarity is slow and the degree of capillary saturation $(\mathrm{Si})$ is small $(25.2 \%)$. Desorption curves show that the Oligocene sandstone

TABLE 1. Composition, grain size and sorting of the three lithotypes based on the petrographic analysis by optical microscopy. RF: Rock Fragment

\begin{tabular}{|c|c|c|c|}
\hline & $\begin{array}{l}\text { Oligocene } \\
\text { sandstone }\end{array}$ & $\begin{array}{l}\text { Quaternary } \\
\text { sandstone }\end{array}$ & $\begin{array}{c}\text { Quaternary } \\
\text { conglomerate }\end{array}$ \\
\hline Extrabasinal grains (\%) & 32.1 & 16.9 & 18.6 \\
\hline Quartz-monocrystal. & 19.9 & 9.1 & 10.4 \\
\hline Quartz - coarse polycrystal. & 3.6 & 2.9 & 1.0 \\
\hline Quartz - fine polycrystal. & 1.8 & - & 1.0 \\
\hline Detrital K-feldspar & 3.4 & - & - \\
\hline K-feldspar in plutonic RF & 0.3 & - & - \\
\hline Sandstone RF & - & 3.3 & 3.9 \\
\hline Metamorphic RF & 0.6 & - & - \\
\hline Chert fragment & 0.9 & - & 0.9 \\
\hline Micritic mudstone RF & 1.6 & 1.6 & 1.4 \\
\hline Intrabasinal grains (\%) & 44.8 & 13.2 & 15.2 \\
\hline Bioclasts & - & 8.8 & 1.9 \\
\hline Bryozoans & 18.6 & 0.8 & - \\
\hline Gastropods & - & - & 5.4 \\
\hline Echinoderms & 2.3 & 1.6 & - \\
\hline Bivalves & 3.3 & - & 7.9 \\
\hline Red algae & 20.6 & 2.0 & - \\
\hline Cement (\%) & 21.2 & 26.2 & 15.2 \\
\hline Intergranular calcite & 5.9 & 34 & 15.3 \\
\hline Intergranular micritic calcite & 0.6 & - & - \\
\hline Calcite replacing detrital grains & 7.8 & - & - \\
\hline Calcite overgrowths & 6.9 & 9.1 & 3.3 \\
\hline Intragranular calcite in & - & - & 2.4 \\
\hline Porosity (\%) & 1.9 & 26.8 & 45.2 \\
\hline Intergranular & 1.6 & 26.3 & 34.8 \\
\hline Intragranular & 0.3 & 0.5 & 10.4 \\
\hline Grain size $(\mathrm{mm})$ & $0.2-0.5$ & $0.3-1.0$ & $5-12$ \\
\hline Sorting & Very well sorted & Well sorted & Poorly sorted \\
\hline
\end{tabular}

preserves a significant water content after 100 hours, which approximately reachs $41 \%$ (Fig. 8B).

The Quaternary sandstone is characterized by a very high value of water absorption under vacuum conditions $(16.6 \%)$ (Table 3$)$. This lithotype absorb water by capillarity very quickly under ambient conditions, with a capillary absorption coefficient of $19 \mathrm{Kg} / \mathrm{m}^{2} \mathrm{~h}^{1 / 2}$ (Fig. 8A). The degree of saturation of water by capillarity remains relatively low by an average of $54.3 \%$. Desorption curves, however, show that the water content after 100 hours is approximately $4.7 \%$ (Fig. 8B).

Regarding the compressive strength, the Oligocene sandstone is the more resistant lithotype to compression (1.17MPa), showing considerably higher values than the Quaternary sandstone (0.12MPa) and Quaternary conglomerate (0.06MPa) (Table 4).

\section{Accelerated artificial aging}

The visual inspection of the tested rock cubes before and after the accelerated artificial aging indicates that the Oligocene and Quaternary sandstones are slightly affected by such test in terms of colour change, fissures, exfoliation, etc. (Fig. 9). Moreover, the results of test indicate that both lithotypes are quite resistant to saline attack as there is not a significant loss of mass (Figs. 9; 10). The loss of mass at the end of the test is very similar in both cases being on average $1.7 \%$ for the Oligocene sandstone and $1.12 \%$ for the Quaternary sandstone. These values are related to the initial and final weight, and thus represent an effective loss of mass.

Despite the similar loss of mass, the absorption dynamics of the salt solution of the studied lithotypes is significantly different (Fig. 10). The Oligocene sandstone absorbs less saline solution than the Quaternary sandstones (maximum water content (Ws) of $0.35 \%$ and $16.6 \%$, 
respectively). Therefore, the absorption of the saline solution occurs at higher rate for the Quaternary sandstone as is also indicated by the capillary absorption coefficient of $19 \mathrm{Kg} / \mathrm{m}^{2} \mathrm{~h}^{1 / 2}$ for the Quaternary versus $0.04 \mathrm{Kg} / \mathrm{m}^{2} \mathrm{~h}^{1 / 2}$ for the Oligocene.

\section{DISCUSSION}

\section{Origin of the building stones}

The Oligocene succession, which includes sandstones and marls, form the Tchemmis hill on top of which the city of Lixus was built. Therefore, these sandstones constitute the local building stone, and thus was the most used lithotype in the construction of the city (Figs. 2; 3A; 5). The location of the historical stone quarries in the Tchemmis hill, probably roman in origin, is evidenced by the presence of extraction marks still preserved in the rock (Fig. 4B). According to the lithostratigraphic section, the largest blocks found in the base of the walls of most important buildings of the city were taken from the second morphological step of the hill (Fig. 3A), corresponding in the log to the stretch between 67 to $74 \mathrm{~m}$ (Fig. 5).

The Quaternary sandstone and conglomerate lithotypes are relatively recent coastal deposits that crop out along the Atlantic coast of Larache. The exact location of the quarries has not been identified although they were most probably exploited from the Larache cliff where equivalent sandstones and conglomerates have been observed (Fig. 6). This location is very close to the harbour and around $4 \mathrm{~km}$ far from Lixus, suggesting that the transport of the building rocks until the site was most probably done by boat along the river Loukkos. Most important characteristic of both the
TABLE 2. Apparent density, relative density and total accessible porosity of the Oligocene and Quaternary sandstones. Values represent an average of six measurements for each lithotype

\begin{tabular}{lccc}
\hline Lithotype & $\begin{array}{c}\text { Apparent } \\
\text { density } \\
\left(\mathrm{g} / \mathrm{cm}^{3}\right)\end{array}$ & $\begin{array}{c}\text { Relative } \\
\text { density } \\
\left(\mathrm{g} / \mathrm{cm}^{3}\right)\end{array}$ & $\begin{array}{c}\text { Water } \\
\text { accessible } \\
\text { porosity }(\%)\end{array}$ \\
\hline $\begin{array}{l}\text { Oligocene } \\
\text { sandstone } \\
\begin{array}{l}\text { Quaternary } \\
\text { sandstone }\end{array}\end{array}$ & $2.65 \pm 0.01$ & $2.68 \pm 0.01$ & $0.9 \pm 0.02$ \\
\hline
\end{tabular}

Quaternary sandstone and the Quaternary shell-rich conglomerate cropping out in the Larache cliff section is the high degree of porosity typical of shoreline recent deposits, which likely facilitated the mining and shaping of the rock.

\section{Rock quality}

Analytical results indicate that the Oligocene sandstone, which is definitely the most used lithotype, is a high-quality rock in terms of the potential alteration by water (i.e. hydric properties) and resistance to compressive efforts (i.e. mechanical properties). Firstly, the results of the hydric tests evidence that the Oligocene sandstones absorb water with difficulty (Fig. 8A), and thus the deterioration of the rock matrix associated with the flow of water in the pore network is not significant. This behaviour is attributed to the low percentage of porosity and poor communication between pores as well as the absence of clay minerals (Navarro, 1993; Zoghlami, 2004; Zoghlami and Gómez-Gras, 2009) (Figs. 7A; Table 2). Moreover, the rate of desorption is slow and shows interruptions as indicated by the shape of the curve (Fig. 8B), confirming a poor communication within the pore system.
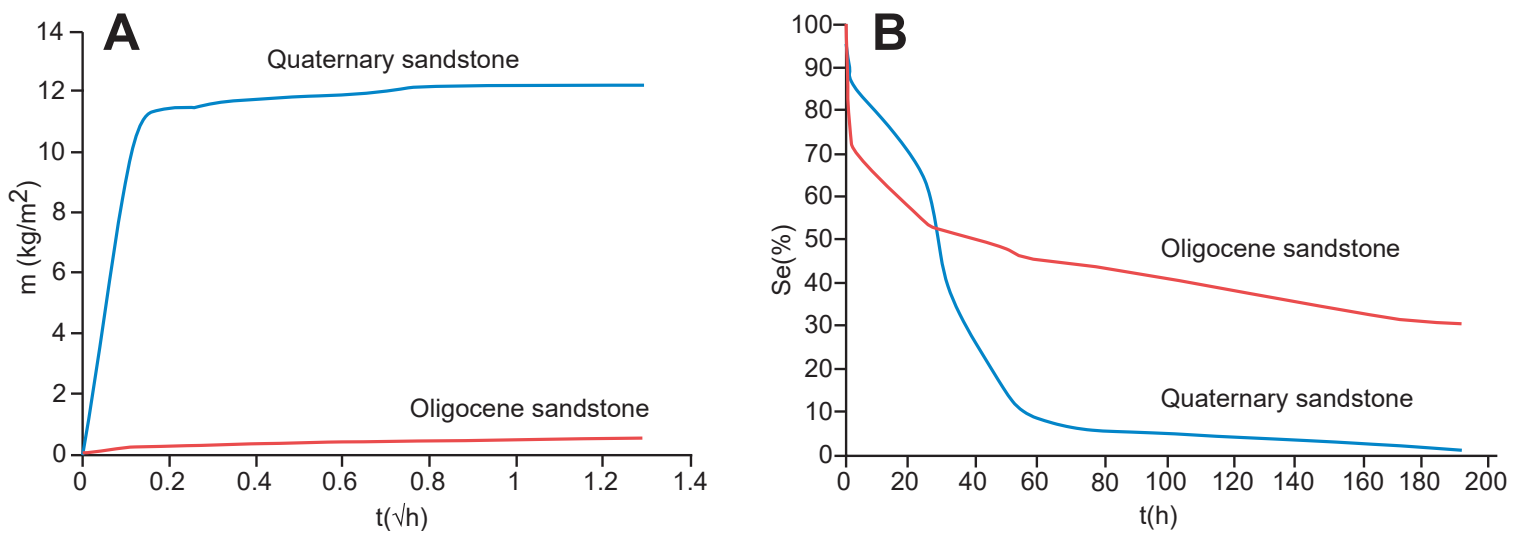

FIGURE 8. Hydric properties of the Oligocene sandstone (red) and Quaternary sandstone (blue). A) Capillary absorption curves showing very significant differences in the absorption of water between both lithotypes. B) Desorption curves of the Oligocene sandstone (red) and Quaternary sandstone (blue) showing the difference in water loss between both lithotypes. Values represent an average of six measurements for each lithotype. 
TABLE 3. Hydric parameters of the Oligocene and Quaternary sandstone lithotypes. Ws: water saturation under vacuum; c.A.C coefficient water capillary absorption; Si: capillary saturation degree; Se: final water content at the end of the dry process. Values represent an average of six measurements for each lithotype

\begin{tabular}{lcccc}
\hline Lithotype & $\begin{array}{c}\text { Ws } \\
(\%)\end{array}$ & $\begin{array}{c}\text { c.A.C } \\
\left(\mathrm{kg} /\left(\mathrm{m}^{2 *} \mathrm{~h}^{1 / 2}\right)\right)\end{array}$ & $\begin{array}{c}\mathrm{Si} \\
(\%)\end{array}$ & $\begin{array}{c}\mathrm{Se} \\
(\%)\end{array}$ \\
\hline $\begin{array}{l}\text { Oligocene } \\
\text { sandstone } \\
\begin{array}{l}\text { Quaternary } \\
\text { sandstone }\end{array}\end{array}$ & $0.35 \pm 0.07$ & $0.04 \pm 0.02$ & $25.2 \pm 3.4$ & $41 \pm 1.7$ \\
\hline
\end{tabular}

Secondly, analytical results indicate that the Oligocene sandstone is considerably more resistant to compression than the Quaternary sandstones, and presumably than conglomerates too, and thus its capacity to support the weight of architectural elements is the highest of the three lithotypes (Table 4). Such a high resistance is attributed to the effect of diverse rock characteristics like grain size distribution, rock fabric, degree of cementation, and porosity (Siegesmund, 1996; Zoghlami et al., 2004).

\section{Deterioration related to climatic conditions}

This section analyses the climate conditions of the studied area and its potential influence in the low level of rock alteration observed in the building stone used in the construction of Lixus. Rock damage caused by weather conditions typically includes the effect of water, ice, moisture, soluble salts, and air pollutants, among others (Graue et al., 2013). Firstly, the moderate temperatures and low rates of precipitation typical of Lixus most probably prevented a significant weathering of both mechanical and chemical types of the building rock. Accordingly, the plot of the climate characteristics of Lixus in the Peltier diagram, which relates temperature and precipitation with weathering, predict a low degree of weathering (Nagel, 2000). Secondly, and despite the lack of analytical data, air pollution in Lixus is not relevant due to its location in a rural area with low density of population. In this regard, Lixus is around

TABLE 4. Compressive strength of the three lithotypes. Note that all values represent an average of six measures for each lithotype

\begin{tabular}{|c|c|}
\hline Lithotype & $\begin{array}{l}\text { Compressive Strength } \\
(\mathrm{MPa})\end{array}$ \\
\hline $\begin{array}{l}\text { Oligocene } \\
\text { sandstone }\end{array}$ & $1.17 \pm 0.11$ \\
\hline $\begin{array}{l}\text { Quaternary } \\
\text { sandstone }\end{array}$ & $0.12 \pm 0.06$ \\
\hline $\begin{array}{l}\text { Quaternary } \\
\text { conglomerate }\end{array}$ & $0.06 \pm 0.11$ \\
\hline
\end{tabular}

$4 \mathrm{~km}$ far from the city of Larache (125000 inhabitants) where major activities are fishing and agriculture. Finally, a potentially important factor in the alteration of the building stone of Lixus could be associated with the presence of salt $(\mathrm{NaCl})$ in the environment, which is related to its location in the proximity of the Atlantic coast (Cardell et al., 2003, 2008; Colston et al., 2001; Ouacha et al., 2013; Silva and Simăo, 2009; Urosevic et al., 2013). Accordingly, the results of the accelerated artificial aging test of the lithotypes in Lixus indicate a slight increase in the mass after the test, which is interpreted to result from the crystallization of salt inside the pore network (Figs. 9; 10). However, the disruptive action of the salt crystallisation within the rock mass is not significant as the real loss of mass is approximately $1 \%$ for the two lithotypes. According to Arnold and Zehender (1989), the alteration associated with salt tend to be more intense with increasing porosity and pore diameter, and thus the Oligocene lithotypes is supposed to be less ready to alteration than the Quaternary one.

In the case of the Oligocene sandstone, the low porosity $(0.9 \%)$ and low saturation rate $(\mathrm{Ws})$ is interpreted to prevent the circulation of fluids and to avoid salt crystallisation inside the rock (see Arnold and Zehender, 1989; Van et al., 2007). Accordingly, the high resistance to salt crystallization during the aging test is attributed to the small pore size of this lithotype (Figs. 9; 10). The high compressive strength and hydric properties, which are characterized by high dry rate and low retention, play a key role in conferring such resistance to the rock against salt action (Ruedrich and Siegesmund, 2007).

The Quaternary sandstones and conglomerates, which are characterized by a very high porosity $(30.9 \%$ and $45.2 \%$, respectively), have a very well communicated pore network. The Quaternary sandstone absorb water very rapidly under ambient conditions, which is attributed to the high porosity with a very large access diameter (Fig. 8; Tables 2; 3). Therefore, the saline solution goes in and out easily from the rock, resulting in an increase of resistivity against salt impairment as well as ice crystallisation (Navarro, 1993). This is even more evident in the case of the Quaternary conglomerate that shows the highest porosity together with the largest pore radius, which avoids significant crystallization stresses.

\section{CONCLUSIONS}

The study of the building stones used in the construction of the Roman city of Lixus (Larache, Morocco) allows the identification of three major rock types (i.e. lithotypes) labelled as i) Oligocene sandstone, ii) Quaternary 

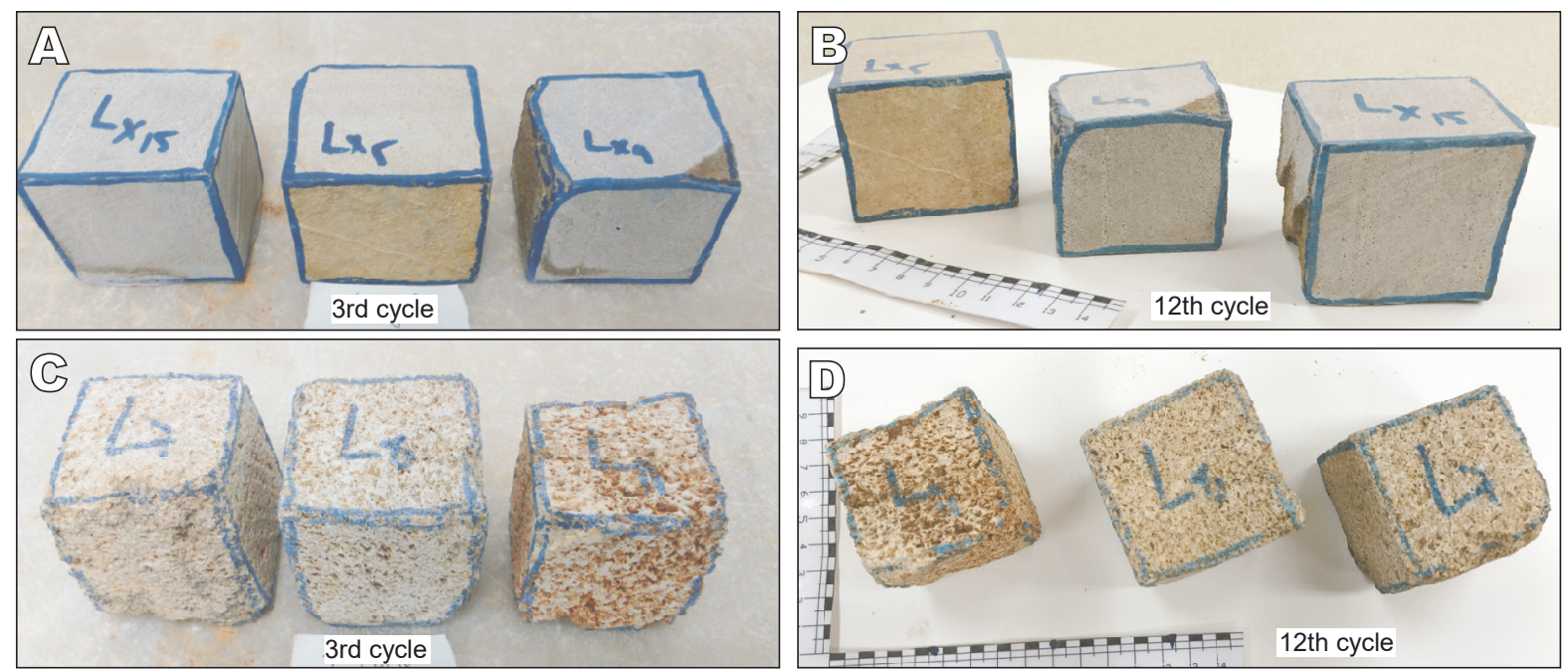

FIGURE 9. Detail view of the cubes used for the artificial aging test showing: A, B) Oligocene sandstone after the $3^{\text {rd }}$ and $12^{\text {th }}$ cycle of the test, respectively; C, D) Quaternary sandstone after the $3^{\text {rd }}$ and $12^{\text {th }}$ cycle of the test, respectively.

sandstone and iii) Quaternary conglomerate. The analysis of the geology surrounding Lixus supported by stratigraphic logging and sampling allows locating the sites from which the lithotypes were quarried. The Oligocene sandstone, which is largely the most used building rock, was directly mined from Tchemmis hill at the top of which Lixus was built. The Quaternary sandstone and conglomerate, which represent recent coastal deposits, were most probably mined from the Atlantic coast of Larache where equivalent rocks facies have been observed.

The performance of petrographic and petrophysics standard tests allows establishing some important characteristics as building rock of the three lithotypes studied here:

i) The Oligocene sandstone shows the best mechanical and hydric properties as a building stone due to the relatively high degree of cementation associated with the lowest porosity values. These properties make this lithotype resistant to both compression and salt crystallization, and presumably to ice too, resulting in a low level of weathering and high level of preservation.

ii) The Quaternary sandstone shows intermediate mechanical properties, resulting from a high porosity and cohesive structure. It shows a good hydric behaviour (high rate of water absorption by capillarity and an almost zero capacity of water retention) because of the high porosity values. These properties make this lithotype to be resistant to weathering by ice and salts due to the easy circulation of fluids in its pore network.

iii) The Quaternary conglomerate shows the worst mechanical properties, which result from the highest porosity $(45.2 \%)$ value of all lithotypes. Its hydric behaviour is good due to the high porosity, which facilitates the entrance and exit of the fluids through the pore system. Despite the artificial accelerated aging test not having been performed for this lithotype, this hydric behaviour indicates that the Quaternary conglomerate would probably have a low degree of deterioration due to salt crystallization.

The results of this study indicate that the generally good state of conservation of the building rocks in the city of Lixus is linked to intrinsic factors such as the petrophysical characteristics together with the gentle climatic conditions of the study area. Finally, the reported results constitute a basis for any potential work aiming to restore and preserve the historic city of Lixus for the benefit of future generations.

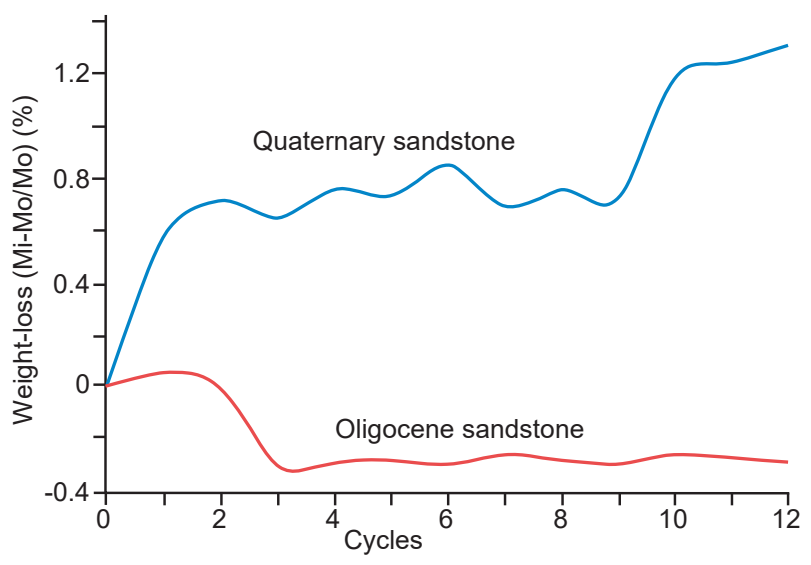

FIGURE 10. Weight-loss curves of the Oligocene sandstone (red) and Quaternary sandstone (blue) showing the behaviour of both lithotypes during salt weathering test. Mi (final weight) and Mo (initial weight). Values represent an average of six measures for each lithotype. 


\section{ACKNOWLEDGMENTS}

This research was funded by the Agencia Española de Cooperación Internacional (AECI, Spain), and supported by the Sedimentary Geology Research Group of the Generalitat de Catalunya (2017-SGR-824). The authors would like to acknowledge the Laboratorio de Materiales del Departamento de Tecnologia de la Arquitectura de la Universidad Politécnica de Catalunya for the collaboration and support in the performance of the petrophysical behaviour, mechanical and salt crystallization aging tests. We thank the reviewers A. Travé and D. Parcerisa, the Editorial Committee of Geologica Acta and the editor B. Alonso for their valuable suggestions to improve this article.

\section{REFERENCES}

Abdelkhaliki, L., 1997. Evolution tectono-sédimentaire des dépots gravitaires des le prérif interne et l'unité du Habt (Rif externe occidental, Maroc): mise en place dans les bassins néogènes d'avant-fosse. Doctoral Thesis. Rabat, Université Mohammed V, 176pp.

Aboumaria, K., Zaghloul, M.N., Battaglia, M., Loiacono, F,, Puglisi, D., Aberkand, M., 2009. Sedimentary processes and provenance of Quaternary marine formations from the Tangier Peninsula (Northern Rif, Morocco). Journal of African Earth Science, 55(1-2), 10-35.

Akil, M., Gayet, J., 1988. Evolution des minéraux lourds dans les formations actuelles et plio-quaternaires de plate-forme et du littoral atlantique marocain. Bulletin de l'Institut de géologie du Bassin d'Aquitaine, 43, 153-161.

Andriani, G.F, Walsh, N., 2007. The effects of wetting and drying, and marine salt crystallization on calcarenite rocks used as building material in historic monuments. Geological Society of London, 271(1, Special Publication), 179-188.

Arnold, A., Zehnder, K., 1989. Salt weathering on monument. The conservation of monuments in the Mediterranean basin. In: Zezza, F. (ed.). Bari (Italy), Proceedings of the First International Symposium, 31-58.

Beaudet, G., 1971. Le quaternaire marocain: état des études. Revue de géographie du Maroc, 20, 3-40

Beck, K, Al-Mukhtar, M., Rozenbaum, O., Rautureau, M., 2003. Characterization, water transfer properties and deterioration in tuffeau: building material in the Loire Valley-France. Building and Environment, 38, 1151-1162.

Beck, K, Al-Mukhtar, M., 2005. Multi-scale characterisation of two French limestones used in historic constructions. International Journal of Restoration of Buildings and Monuments, 11(4), 219-226.

Benavante, D., 2011. Why pore size is important in the deterioration of porous stones used in the built heritage. Macla, 15, 41-42.

Borrelli, E., Urland, A., 1999. ARC Laboratory Handbook. Rome, International Centre for the Study of the Preservation and Restoration of Cultural Property (ICCROM), 3 (Salts), 24pp.
Bouhmadi, B., Benavente, J., Cruz-Sanjulián, J., Sanromá, A., 1995. Caracterización hidrodinámica e hidroquímica de los acuíferos de la Cuenca Baja del río Loukkos (Marruecos). Boletín Geológico y Minero, 106, 161-177.

Cardell, C., Delalieux, F, Roumpopoulos, K., Moropoulou, A., Auger, F, Van Grieken, R., 2003. Salt-induced decay in calcareous stone monuments and buildings in a marine environment in SW France. Construction and Building Materials, 17(3), 165-179.

Cardell, C., Benavente, D., Rodríguez-Gordillo, J., 2008. Weathering of limestone building material by mixed sulphate solutions. Characterization of stone microstructure, reaction products and decay forms. Materials Characterization, 59(10), 1371-1385.

Cazzola, C., Critelli, S., 1987. Litostratigraphia e petrología della quartzoareniti torbitiche oligomioceniche di Asilah (Catena de Rif, Marocco nord-occidental). Mineralogica et Petrographica Acta, XXX, 203-226.

Chabli, A., Chalouan, A., Akil, M., Galindo-Zaldívar, J., Ruano, P., Sanz de Galdeano, C., López-Garrido, A.C., Marín-Lechado, C., Pedrera, A., 2014. Plio-Quaternary paleostresses in the Atlantic passive margin of the Moroccan Meseta: Influence of the Central Rif escape tectonics related to Eurasian-African plate convergence. Journal of Geodynamics, 77, 123-134.

Chalouan, A., Michard, A., 1990. The Ghomarides nappes, Rif coastal range, Morocco: A variscan chip in the Alpine belt. Tectonics, 9, 1565-1583.

Chalouan, A., Michard, A., Feinberg, H., Montigny, R., Saddiqi, O., 2001. The Rif mountain building (Morocco): A new tectonic scenario. Bulletin de la Société géologique de France, 242, 603-616.

Colston, B.J., Watt, D.S., Munro, H.L., 2001. Environmentallyinduced stone decay: the cumulative effects of crystallizationhydration cycles on a Lincolnshire oopelsparite limestone. Journal of Cultural Heritage, 2(4), 297-307.

De Kock, T., De Boever, W., Dewanckele, J., Boone, M.A., Jacobs, P., Cnudde, V., 2015. Characterization, performance and replacement stone compatibility of building stone in the 12th century tower of Dudzele (Belgium). Engineering Geology, 184(14), 43-51.

Derbez, M., Lefèvre, R., 2003. Chemical and mineralogical composition and sources of urban atmospheric particles, specially sulphates-A study at Tours (France). Pollution Atmospherique, 177, 103-126.

Dessandier, D., Antonelli, F., Rasplus, L., 1997. Relationships between mineralogy and porous medium of the crai tuffeau. Bulletin de la Société Géologique de France, 186(6), 741-749.

Didon, J., Durand Delga, M., Kornprobst, J., 1973. Homologies géologiques entre les deux rives du détroit de Gibraltar. Bulletin de la Societé Géologique de France, 7(2), 77-105.

Durand Delga, M., 1964. Essai sur la structure des domaines émergés autour de la Méditerrannée occidentale. Géolische Rundschau, 53(2), 534-535.

El Gharbaoui, A., 1981. La terre et l'homme dans la Péninsule Tingitane: Etude sur l'homme et le milieu naturel dans le rif 
occidental. Travaux de l'Institut scientifique, Serie géologie et géographie physique, 15, 439pp.

El Mekadem, N., El Moutchou, B., 2016. Study of the structural continuity from hinterlands to continental shelf in Larache area (NW Morocco): Morphostructural approach. Journal of Materials and Environmental Science, 7(6), 2114-2120.

El Moutchou, B., Benali, H., Mamouni, A., 2014. Evolution diachronique de la ligne du rivage le long des littoraux méditerranéens occidentaux marocains: cas des sites côtiers de Ksar Esghir, Bou Ahmed et Jebha (Maroc). Journées Nationales Génie Côtier-Génie Civil, 317-324. DOI: 10.5150/ jngcgc.2014.035

Esbert, R.M., Marcos, R.M., 1983. Las piedras de la catedral de Oviedo y su deterioración. Colegio Oficial de Aparejadores y Arquitectos Técnicos de Asturias, Oviedo, Gráficas Summa, $144 \mathrm{pp}$.

Esbert, R.M., Alonso, FJ., Ordaz, J., 2008. La petrofísica en la interpretación del deterioro y la conservación de la piedra de edificación. Trabajos de Geología, 28, 87-95.

Fort, R., Bernabéu, M.A., Garcia del Cura, M.A., López de Azcona, M.C., Ordóñez, S., Mingarro, F., 2002. La piedra de Novelda: una roca muy utilizada en el patrimonio arquitectónico. Materiales de Construcción, 52(266), 19-32.

Gauri, K.L., Punuru, A.R., 1989. Characterization and durability of limestone determined through mercury intrusion porosimetry. Bari (Italy), Proceedings of the 1st International Symposium on the conservation of monument in the Mediterranean Basin, 263-269.

Gigout, M., 1947. Quaternaire du littoral atlantique du Maroc. Les dunes quaternaires du Sahel. Comptes Rendus Sommaires de la Société Géologique de France, 5, 71-73.

Goudie, A.S., 1999. Experimental salt weathering of limestones in relation to rock properties. Earth Surface Processes and Landforms, 24, 715-724.

Graue, B., Siegesmund, S., Oyhantcabal, O., Naumann, R., Licha, T., Simon, K., 2013. The effect of air pollution on stone decay: the decay of the Drachenfels trachyte in industrial, urban, and rural environments-a case study of the Cologne, Altenberg and Xanten cathedrals. Environmental Earth Sciences, 69(4), 1095-1124.

Grossi, G.M., Esbert, R., 1994. Las sales solubles en el deterioro de las rocas monumentales. Revisión bibliográfica. Materiales de Construcción, 54(235), 15-30.

Haddane, M., 1997.Carte Géologique de Maroc 1:50000. Editions du Service Géologique du Maroc, Notes et Mémoires n³82 (Larache).

Kottek, M., Grieser, J., Beck, C., Rudolf, B., Rubel, F., 2006. World map of the Köppen-Geiger climate classification updated. Meteorologische Zeitschrift, 15(3), 259-263.

Lazzarini, L., Laurenzi Tabasso, M., 1986. Il restauro della pietra. Padova, Casa Editrice Dottore Antonio Milani (CEDAM), 320pp.

Lespinasse, P., 1975. Géologie des zones externes et des flyschs entre Chaouen et Zoumi (centre de la chaine rifaine, Maroc).
Doctoral Thesis. Paris, Université Pierre et Marie Curie, 248pp.

López-Arce, P., García-Guinea, J., Benavente, D., Tormo, L., Doehne, E., 2009. Deterioration of dolostone by magnesium sulphate salt: An example of incompatible building materials at Bonaval Monastery, Spain. Construction and Building Materials, 23, 846-855.

Martínez-Martínez, J., Benavente, D., Jiménez, S., García del Cura, M.A., Ordóñez, S., 2017a. Stone weathering under Mediterranean semiarid climate in the fortress of Nueva Tabarca island (Spain). Building and environment, 121, 262276.

Martínez-Martínez, J., Corbí, H., Martin-Rojas, I., Giannetti, A., 2017b. Stratigraphy, petrophysical characterization and 3D geological modelling of the historical quarry of Nueva Tabarca island (western Mediterranean): Implications on heritage conservation. Engineering Geology, 231, 88-99.

Morley, C.K., 1987. Origin of major cross-element zone: Moroccan Rif. Geology, 15, 761-764.

Navarro, A., 1993. Tratamiento de la arenisca del Buntsandstein y del mortero sintético Parrot's Mix 4 con consolidantes e hidrofugantes. Variaciones en el comportamiento petrofísico y en la alterabilidad. Bachelor Doctoral Thesis. Bellaterra, Universidad Autónoma de Barcelona, 97pp.

Nagel, G., 2000. Advanced Geography. Oxford, Oxford University Press, 464pp.

NORMAL 29/88 (1988). Misura dell'indice di asciugamento (Drying Index). CNR-ICR, Roma.

Ouadia, M., Aberkan, M., Aboumaria, K., 2015. Le complexe dunaire quaternaire du Jorf Lasfar (Meseta côtière occidentale marocaine): lithostratigraphie, sédimentologie et néotectonique. Revue Paralia, 8, 1-14.

Ordoñez, S., Fort, R., Garcia del Cura, M.A., 1997. Pore size distribution and the durability of a porous limestone. Quarterly Journal of Engineering Geology, 30, 221-230.

Ouacha, H., Ben Moussa, A., Simao, J., 2013. The salt crystallization weathering of building rocks of the arqueological sites calcarenites of North-Western Morocco (Lixus, Benasa and Thamusida). European Scientific Journal, 9(18), 282-290.

Ponsich, M., 1966. Contribution á l'atlas archéologique du Maroc: région de Lixus. Bulletin d'archéologie marocaine, 6, 377-423.

Price, D.G., 1995. Weathering and weathering processes. Quarterly Journal of Engineering Geology, 28, 243-252.

Robinson, D.A., Williams, R.B.G., 1994. Rock weathering and landform evolution. Wiley, Chichester, 544pp.

Ruedrich, J., Siegesmund, S., 2007. Salt and ice crystallisation in porous sandstones. Environmental Geology, 52, 225-249.

Ruedrich, J., Seidel, M., Rothert, E., Siegesmund, S., 2007. Length changes of sandstones caused by salt crystallization. In: Prikryl, R., Smith, B.J. (eds.). Building Stone Decay: from Diagnosis to Conservation. London, Geological Society, 272, 199-209. 
Samaka, F, Benyaich, A., Dakki, M., Hçaine, M., Bally, A.W., 1997. Origine et inversion des bassins miocènes supra-nappes du Rif central (Maroc). Etude de surfaces et de subsurface. Exemple des bassins de Taounate et de Tafrant. Geodinamica Acta, 10, 30-40.

Siedel, H., Siegesmund, S., 2014. Characterization of stone deterioration on buildings (Chapter 6). In: Siegesmund, S., Snethlage, R. (eds.). Stone in Architecture. Berlin Heidelberg, Springer-Verlag, 349-414.

Siegesmund, S., 1996. The significance of rock fabrics for the geological interpretation of geophysical anisotropies. Geotektonische Forschungen, 85, 1-123.

Silva, Z.S.G., Simăo, J.A.R., 2009. The role of salt fog on alteration of dimension stone. Construction and building materials, 23, 3321-3327.

Suter, G., 1986. Carte Géologique de Marroc 1:50000. Editions du Service Géologique du Maroc, Notes et Mémoires nº 346 (Asilah).

Suter, G., Fiecher G., 1966. Le Rif méridonial atlantique (Maroc). Apercu structural sur la région Ouazzane-Zoumi et le pays de Habt (Larache). Notes et Mémoires du Service Géologique du Maroc, 26(188), 15-20.

Tejera de Leon, J.M., Boutakiout, A., Ammar, L., Aı“t Brahim, El Hatimi, N., 1995. Les bassins du Rif central (Maroc): Marqueurs de chevauchements hors séquence d'âge miocène terminal au coeur de la chaîne. Bulletin de la Societé Géologique de France, 166, 751-761.

Turkington, A.V., Paradise, T.R., 2005. Sandstone weathering: a century of research and innovation. Geomorphology, 67, 229253.

UNE-EN 1925, 1999. Natural stone test methods. Determination of absorption coefficient of water by capillary. Madrid, Asociación Española de Normalización y Certificación (AENOR), 13pp.

UNE-EN 12370, 1999. Método de ensayo para piedra natural. Determinación de la resistencia a la cristalización de las sales. Madrid, Asociación Española de Normalización y Certificación (AENOR), 10pp.

UNE-EN 1926, 2007. Natural stone test methods. Determination of uniaxial compressive strength. Madrid, Asociación Española de Normalización y Certificación (AENOR), 21pp.
UNE-EN 1936, 2007. Natural stone test methods. Determination of real and apparent density and open and total porosity. Madrid, Asociación Española de Normalización y Certificación (AENOR), 13pp.

UNE-EN 12407, 2007. Natural stone test methods. Petrographic examination. Madrid, Asociación Española de Normalización y Certificación (AENOR), 19pp.

Urosevic, M., Sebastian, E., Cardell, C., 2013. An experimental study on the influence of surface finishing on the weathering of a building low-porous limestone in coastal environments. Engineering Geology, 154, 131-141.

Van, T.T., Beck, K., Al-Mukhtar, M., 2007. Accelerated weathering tests on two highly porous limestones. Environmental Geology, 52(2), 283-292.

Villegas, R., Vale, J.F., 1993. Evaluación de tratamientos de hidrofugación aplicados a piedras de catedrales andaluzas. III.- Ensayo de alteración acelerada en atmósfera contaminada. Materiales de construcción, 43, 232, 25-38.

Winkler, E.M., 1975. Stone: Properties, durability in Man's environment. Spring-Verlag, Wien New York, 230pp.

Zaouia, N., EL Wartiti, M., Nahraoui, FZ., Dabi, S., 2014. Etude de l'altération de la calcarénite des monuments de Rabat: Influence de la Pollution Atmosphérique et des Aérosols Marins. MATEC Web of conferences, 11, 03015.

Zehnder, K., Arnold, A., 1989. Crystal growth in salt efflorescence. Journal of crystal growth, 97(2), 513-521.

Zoghlami, K., Gómez-Gras, D., Álvarez, A., De Luxán, MP., 2004. Intrinsic factors that condition the physical behaviour and the durability of the Miocene sandstones used in the construction of the Roman aqueduct of Zaghouan-Carthage. Materiales de Construcción, 54(276), 29-41.

Zoghlami, K., Gómez-Gras, D., 2009. Petrophysical behaviour and durability of the Miocene sandstones used in the architectural heritage of Tunisia (Roman aqueduct of Oued Miliane and Uthina Roman site). Journal of African Earth Science, 55(1), 1-9.

Zoghlami, K, Martín-Martín, J.D., Gómez-Gras, D., Navarro, A., Parcerisa, D., Rosell, J.R., 2017. The building stone of the Roman city of Dougga (Tunisia): Provenance, petrophysical characterisation and durability. Comptes Rendus Geoscience, 349, 402-411.

\footnotetext{
Manuscript received September 2019;

revision accepted July 2020;

published Online August 2020.
} 